\section{The Importance of Social Support in the Case of Abuse and Child Neglect}

[Importanța suportului social în cazurile de abuz şi neglijare a copilului]

\section{Oana Lăcrămioara BĂDĂRĂU ${ }^{1}$}

${ }^{1}$ Lecturer $\mathrm{PhD}$, ,Petre Andrei” University of Iasi, Romania, Email:

oanabadarau2000@yahoo.co.uk

\begin{abstract}
The purpose of this paper is to present and analyze some characteristics of the social relationships system which is specific to families where child abuse and neglect occur. The theoretical considerations are structured around a set of questions, such as: What role do social networks have in family life in general and in every member of the family in particular? How does the network of social relationships differentiate between families where children are subjected to different forms of abuse or neglect from families where there are no such events? What is the relationship between the different characteristics of parents' social networking and child maltreatment? As part of the social network of family members, support system can prevent child maltreatment? What is the impact of an episode of child abuse and neglect on the social network configuration? Concrete evidence shows that there is a relationship between the quality of the parents' social network and child maltreatment, and that the social support system plays an important role in preventing such incidents.
\end{abstract}

Keywords: social network; social support; cbild abuse; child neglect.

How to cite: Badarau, O.L. (2017). The Importance of Social Support in the Case of Abuse and Child Neglect. Anuarul Universitatii "Petre Andrei" din lasi, Fascicula: Asistenta Sociala, Sociologie, Psihologie, 19, 49-60. https://doi.org/10.18662/upasw/02 


\section{Introducere}

Înţelegerea mediului social imediat (prin analiza sistemului de relații sociale şi a diverselor forme de interacțiune) în care îşi desfăşoară viața un individ, cuplu sau o familie reprezintă o dimensiune relevantă pentru creionarea imaginii de ansamblu asupra unui caz şi pentru proiectarea unui plan de intervenție eficient. Suportul social reprezintă principala resursă externă la care o persoană poate apela, pentru evitarea sau rezolvarea anumitor probleme pe care nu le poate depăşi singură. Suportul social reprezintă o resursă centrală pentru dezvoltarea şi bunăstarea umană, o dimensiune majoră a comportamentului social, care este situată la interfața dintre individ şi sistemul social din care acesta face parte (Orford, 2003). De asemenea, el poate contribui la menținerea sănătății fizice şi psihice a individului, la integrarea în mediul social, la creşterea stimei de sine şi la nevoia individului de a avea încredere în oameni şi de a se simţi în siguranţă. Măsurarea suportului social se realizează prin evaluarea structurii şi a funcționării relațiilor sociale. Astfel, în timp ce suportul structural reflectă interacțiunile sociale, rețelele şi legăturile sociale, suportul funcțional se centrează pe calitatea funcționării specifice diverselor forme de sprijin. Unii cercetători consideră că măsurarea suportului structural implică analiza cantitativă a rețelelor sociale (numărul persoanelor de suport sau frecvența legăturilor suportive), în timp ce măsurarea suportului funcțional se realizează prin analiză calitativă a suportului (indicatori referitori la valoare sau la importanță). Aşadar, suportul social funcțional se referă la sprijinul instrumental (material), informațional şi emoțional, pe care o persoană îl obține în contextul relațiilor sale sociale şi comunitare (Baron-Cohen, Leslie şi Frith, 1985).

P. Iluț (1997) defineşte noțiunea de rețea socială ca fiind un sistem de legături datorate unui tip specific de relații stabilite într-o mulțime dată de unități sociale (persoane, grupuri, evenimente etc.). Rețeaua socială a unui individ este constituită dintr-un ansamblu de relaţii sociale care variază în funcție de mai mulți factori, cum ar fi: îndeplinirea diverselor roluri sociale, contextul vieții socioculturale, satisfacerea anumitor nevoi psihosociale resimţite în cursul vieții sau în situaţii de criză etc. Orice persoană conviețuieşte în cadrul unor rețele sociale formale sau informale. Gradul de conectivitate al acestora asigură socializarea, adaptabilitatea şi funcționarea socială la parametrii optimi (Buzducea, 2005). Rețeaua de relații sociale joacă un rol central atât în funcţionarea unui sistem familial, cât şi în creşterea şi educarea copiilor. O rețea de relații sociale puternică este o resursă 
importantă pentru familiile aflate în situații de dificultate. Însă, în acelaşi timp, relațiile pot fi distructive, ele pot deveni obstacole în rezolvarea diferitelor probleme. În practică, este necesară includerea analizei configurației rețelei de relații sociale, care să permită identificarea şi evaluarea atât a potențialelor resurse pentru suport pe care le poate utiliza familia, cât şi a eventualelor surse de tensiuni sau conflicte.

In cadrul acestei lucrări, argumentația teoretică se structurează în jurul unui set de întrebări, precum: Ce rol au rețelele sociale în viața familiei, în general şi a fiecărui membru al familiei, în particular? Prin ce se diferențiază rețeaua de relații sociale în familiile în care copiii sunt supuşi diferitelor forme de abuz sau de neglijare de cea a familiilor în care nu se petrec astfel de evenimente? Care este legătura dintre diferitele caracteristici ale rețelei de relaţii sociale ale părinţilor şi maltratarea copilului? Ca parte a rețelei sociale a membrilor unei familii, sistemul de suport poate preveni maltratarea copilului? Care este impactul unui episod de abuz sau neglijare a copilului asupra configurației rețelei sociale a acestuia?

\section{Legătura dintre calitatea rețelei sociale a părinţilor şi maltratarea copiilor}

Rezultatele mai multor cercetări au evidențiat corelația strânsă dintre calitatea rețelei sociale a părinților şi maltratarea copilului. Astfel, Gaudin (2001) sugerează faptul că părinții care îşi neglijează sau abuzează copiii primesc, la rândul lor, mai puțin sprijin din partea familiilor de origine şi a prietenilor lor, comparativ cu părinții care nu îşi neglijează sau abuzează copiii. După acelaşi autor, factorii care contribuie la calitatea suportului social sunt: conținutul contactelor sociale, frecvența acestora, eterogenitatea rețelei de sprijin şi satisfacția mamelor cu privire la relaţia cu membrii din rețea. Evaluările familiei ar trebui să identifice membrii rețelei de sprijin şi caracteristicile persoanelor/rețelei de contact, precum şi relațiile familiei cu serviciile sociale formale şi organizațiile din comunitate. Programele care au succes în îmbunătățirea suportului social şi a abilităților parentale includ mai multe strategii de intervenție, inclusiv împuternicirea familiei (engl. empowerment of family), consilierea de grup, oferirea de cursuri de îngrijire a copilului şi de educație parentală, formarea abilităţilor sociale, orientarea profesională sau consilierea în carieră etc.

Într-o trecere în revistă a cercetărilor referitoare la izolarea socială a familiilor în care au avut loc episoade de abuz şi/sau neglijare a copilului, C. Coohey (1996) considera că izolarea socială nu este un factor etiologic pentru relele tratamente aplicate copilului, ci se referă, mai degrabă, la un set 
de variabile legate de percepția părintelui cu privire la suport şi la rețelele formale şi informale. In studiul său, Coohey a comparat două grupuri de mame cu venituri mici (un grup de mame care îşi maltrataseră copiii cu un grup de mame care nu-şi expuseseră copiii la astfel de incidente), identificând variații considerabile între rețelele celor două grupuri cu privire la proprietățile structurale, tipurile de resurse pe care le primeau, precum şi cu privire la percepția asupra cantităţii şi calităţii suportului social. Rezultatele aceluiaşi studiu au indicat faptul că, în comparaţie cu mamele nonabuzive, cele care îşi abuzaseră proprii copii primeau, în general, mai puțin sprijin din partea membrilor rețelei sociale. Totodată, mamele care îşi neglijaseră copiii aveau mai puțini membri în rețeaua socială, mai puține contacte şi primeau mai puțin sprijin emoțional şi instrumental, comparativ cu mamele care îşi abuzaseră fizic copiii.

Deşi efectuată pe un eşantion restrâns de mame $(\mathrm{N}=34)$, cercetarea realizată de Bishop şi Leadbeater (1999) a condus la următoarea concluzie: în comparație cu mamele nonabuzive, cele abuzive primeau mai puțin suport de la prieteni. În schimb, între cele două grupuri de mame, nu au existat diferențe în ceea ce priveşte suportul primit de la rude. Studiul citat a analizat calitatea sprijinului social în funcție de vârstă, educație, numărul de copii, vârsta copiilor şi alte caracteristici demografice. Comparativ cu mamele din grupul de control, cele care îşi maltrataseră copiii aveau mai puțini prieteni în rețelele lor de sprijin social, se întâlneau mai rar cu aceştia, iar calitatea suportului social era mai slabă.

Intr-un alt studiu, Coohey (2001) a realizat o analiză a sistemelor de rețele sociale (tipuri de relații, caracteristicile membrilor din rețeaua de prieteni şi rude, interesul mamelor analizate pentru a primi suport emoțional din partea rudelor) pentru un număr de 172 de mame, după cum urmează: 51 de mame nonabuzive de origine engleză, 51 de mame abuzive de origine engleză, 35 de mame nonabuzive de origine latină şi 35 de mame abuzive de origine latină. Analiza rețelei de sprijin a mamelor nonabuzive comparativ cu cea a mamelor abuzive a condus la următoarele rezultate: a) comparativ cu mamele abuzive, cele nonabuzive au raportat mai mulți prieteni apropiați şi mai multe rude în rețelele lor sociale; b) comparativ cu mamele abuzive, cele nonabuzive aveau mai multe contacte cu rudele lor; c) de asemenea, comparativ cu mamele abuzive, mamele nonabuzive primeau mai mult suport din partea rudelor. Analiza rețelei de suport a mamelor participante la studiu, în funcție de originea etnică a acestora, a evidențiat următoarele aspecte: a) comparativ cu mamele de origine engleză, cele de origine latină considerau că au mai multe rude apropiate; b) comparativ cu mamele de origine latină, mamele de origine engleză au tins să raporteze că rudele lor 
aveau mai multe caracteristici negative; c) interesul mamelor de origine latină pentru a primi suport emoțional din partea rudelor a fost similar cu cel al mamelor de origine engleză; d) comparativ cu mamele de origine latină din grupul de control (nonabuzive), cele de origine latină care îşi abuzaseră copiii aveau mai puține rude pe care le percepeau ca apropiate, erau mai tinere şi aveau mai puține contacte cu prietenii; e) în comparație cu mamele de origine engleză din grupul de control, cele abuzive aveau mai puțini prieteni apropiați şi manifestau mai puțin interes pentru a primi suport emoţional. În funcție de venit, statutul pe piaţa muncii sau numărul de copii pe care îi aveau în creştere, nu s-au constatat diferențe semnificative statistic între mamele abuzive şi cele nonabuzive de origine engleză, respectiv latină. În schimb, comparativ cu mamele nonabuzive de origine engleză, cele abuzive de aceeaşi etnie erau mai predispuse să locuiască singure alături de copiii lor. De asemenea, în comparație cu mamele nonabuzive de origine latină, cele abuzive erau mai tinere. La rândul lui, nivelul educației a fost diferit pentru cele două grupuri etnice analizate: în medie, mamele de origine latină aveau studii cu doi sau trei ani mai puțini decât mamele de origine engleză (Coohey, 2001).

În cadrul unui studiu de dată mai recentă, Coohey (2007) şi-a propus să afle dacă sprijinul oferit de membrii familiei şi de prieteni pentru îngrijirea copiilor este corelat cu neglijarea acestora (lipsa supravegherii). Eşantionul a fost constituit dintr-un număr de 32 de mame cu venituri mici care nu-şi supravegheau în mod corespunzător copiii şi 32 de mame dintr-un grup de control, care asigurau o supraveghere adecvată a copiilor. Rezultatele au indicat faptul că mamele din primul grup primeau mai puțin sprijin pentru îngrijirea copiilor din partea partenerilor de viaţă şi a rudelor, comparativ cu mamele din grupul de control. Aceste diferențe păreau să fie legate de mai multe caracteristici ale rețelelor sociale ale mamelor. De exemplu, majoritatea celor care nu-şi supravegheau adecvat copiii fie nu aveau un partener de viaţă, fie aveau unul, dar îl cunoscuseră cu mai puțin de un an în urmă. De asemenea, mamele care nu-şi supravegheau în mod corespunzător copiii aveau mai puțini membri de familie care locuiau în vecinătate şi mai multe relații negative cu aceştia.

În ceea ce priveşte rețeaua de suport a taților, Coohey (2000) a descoperit într-un alt studiu comparativ faptul că taţii care îşi abuzau fizic copiii primeau mult mai puţin sprijin emoțional şi material din partea rudelor sau a prietenilor, în comparație cu suportul de care beneficiau tații nonabuzivi. Legăturile cu membrii rețelelor sociale, consideră autoarea studiului, ar fi putut descuraja impulsurile agresive ale taţilor sau ar fi putut furniza sprijin suplimentar pentru ei şi familiile lor. 


\section{Tipologia familiilor în care copiii sunt abuzați şi / sau neglijați în funcție de particularitățile rețelei sociale}

P. Crittenden (1988) a constat că, în comparație cu mamele dintr-un grup de control, cele care îşi neglijau copiii beneficiau de mai puțin sprijin emoțional din partea prietenilor, dar fiecare grup de mame primea în egală măsură sprijin emoțional din partea familiei (rudelor). În contextul acestui studiu, mamele au fost rugate să descrie relațiile lor sociale pornind de la cinci persoane pe care le cunoşteau foarte bine. Participantele la studiu au fost întrebate despre relația cu fiecare persoană numită (de exemplu: rudă, prieten, coleg din mediul profesional etc.), perioada de timp de când cunoşteau acea persoană, periodicitatea întrevederilor cu ea, ajutorul primit de la acea persoană, precum şi despre gradul încrederii pe care o aveau în acea persoană. Răspunsurile mamelor au fost grupate, pentru a se descrie trei tipuri de rețele de relaţii personale. Reţele stabile-deschise formate atât din rude, cât şi din prieteni pe care mamele îi cunoşteau, în medie, de cinci ani şi cu care se întâlneau de cel puţin trei ori pe săptămână. Aceste tipuri de relații erau reciproce şi demne de încredere. Rețele stabile-inchise formate, aproape exclusiv, din relaţii în care persoanele se întâlneau zilnic, dar care nu erau reciproce şi despre care mamele credeau că nu sunt demne de încredere. Reţele instabile-deschise alcătuite, în principal, din prieteni pe care mamele îi cunoșteau de cel mult un an, dar cu care se întâlneau frecvent şi care erau considerate relații nereciproce şi nedemne de încredere. În funcție de aceste tipuri de rețele sociale, Crittenden (1988) a identificat şi a analizat următoarele tipuri de familii:

$\checkmark$ Familiile in care au loc incidente de abuz asupra copilului se caracterizează prin multe contacte sociale, dar prin relații de scurtă durată şi nereciproce. Rețelele sociale ale unor astfel de familii ar putea fi descrise ca fiind instabile-deschise.

$\checkmark$ Familizle in care an loc episoade de neglijare a copilului au rețele stabile-închise, de cele mai multe ori limitate la contacte sociale doar cu membrii familiei.

$\checkmark$ Familiile în care există atât cazuri de abu₹, cât și de neglijare sunt instabile din punct de vedere structural şi dezorganizate. Sunt familii numeroase, alcătuite din mai mulți membri şi care au, de regulă, copii născuți din tați diferiți. Părinții nu posedă abilităţile sociale şi pe cele de creştere a copilului, care sunt necesare pentru a face față situațiilor complexe.

$\checkmark$ Familiile marginalizate sunt cele în care abuzul sau neglijarea copilului nu a fost destul de sever astfel încât să beneficieze de asistență. Rețeaua de relaţii sociale se caracterizează prin legături familiale puternice, dar schimbătoare. Structura familiei variază mult şi a fost definită ca instabilă. 
$\checkmark$ Familiile adecvate (functionale) sub aspectul rețelei de suport social au contacte frecvente cu rudele şi numeroşi prieteni pe termen lung. Rețelele sociale ale unor astfel de familii sunt stabile-deschise.

Aşadar, aşa cum reiese şi din studiul realizat de Crittenden, în general, părinții care îşi neglijează sau abuzează copiii au mai puțini membri în rețelele lor sociale, interacționează mai puțin cu rudele şi primesc mai puțin sprijin decât părinţii care nu îşi maltratează copiii. Relele tratamente aplicate minorilor sunt asociate cu izolarea familiilor de grupurile de suport, rețelele de cartier, familiile extinse, activitățile din comunitate sau de alte sisteme de asistență socială care sunt importante pentru bunăstarea individuală a membrilor unei familii şi a acesteia, privită ca sistem. Atunci când se confruntă cu stresul, familiile care îşi neglijează sau abuzează copiii se confruntă cu lipsa unor membri ai rețelei sociale, cărora să li se adreseze pentru sprijin. Aceste constatări sugerează că practicienii care lucrează cu părinţi aflaţi în riscul de a-şi neglija sau abuza copii ar trebui să identifice resursele rețelei de rude şi de prieteni ca potenţiale repere pentru acordarea unui suport emoțional adecvat dificultăților cu care se confruntă. S-a constatat că suportul emoțional servește ca un tampon împotriva efectelor negative produse de diverşi factori de stres, precum lipsa resurselor financiare. În plus, cu cât este mai mare numărul membrilor rețelei care oferă sprijin emoţional mamelor, cu atât este mai puțin probabil ca ele să îşi abuzeze fizic copiii (Coohey, 1996).

Comparativ cu familiile neglijente, în familiile care se confruntă cu incidente de abuz asupra copiilor, problemele sociale pot fi diferite. Rezultatele mai multor studii sugerează faptul că izolarea socială poate fi o caracteristică puternică a familiilor care îşi neglijează copiii, în timp ce conflictul social poate caracteriza mai frecvent familiile abuzive (Coohey, 1996). Însă, lipsa sprijinului social pare să caracterizeze toate tipurile de maltratare. Suportul nu reflectă numai ceea ce este disponibil în mediul social al unei persoane sau familii. Este vorba, de asemenea, de abilitatea unei persoane/familii de a atrage, obține şi menține suportul. Resursele sociale pentru sprijin ar putea fi disponibile, dar multe familii în care au loc episoade de abuz şi/sau neglijare a copiilor nu reuşesc să le acceseze. Astfel, este important să se facă distincția dintre lipsa suportului disponibil şi eşecul de a folosi suportul disponibil, precum şi diferențierea dintre sprijinul perceput (engl. perceived social support) şi suportul efectiv primit (engl. enacted social support) (Coohey, 1996). 


\section{Configurația rețelei sociale a copiilor care au fost supuşi diferitelor forme de abuz sau neglijare}

J. G. Noll, P. K. Trickett şi F. W. Putnam (2000) au examinat legătura dintre configuraţia rețelei sociale, calitatea relaţiilor afective şi sociale (inclusiv a celor de ataşament din perioada copilariei şi a adolescenței timpurii), respectiv atitudinea față de activitatea sexuală în adolescența târzie şi, apoi, la vârsta adultă. De asemenea, autorii studiului au analizat diferențele determinate de diferite tipuri de relații dintre un grup de fete care fuseseră victime ale abuzului sexual şi un grup de control. La prima vedere, autorii studiului citat au constatat că nu existau diferențe prea mari între cele două grupuri de fete, în ceea ce privea structura rețelei sociale, respectiv nivelul satisfacției faţă de relațiile cu persoanele de acelaşi sex sau de sex opus, respectiv persoanele cu aceeaşi vârstă sau cu vârste mai mari. În schimb, autorii studiului au constatat că diferențele dintre cele două grupuri de fete tindeau să apară în perioada adolescenței târzii şi la maturitate, atunci când victimele abuzului sexual aveau primul contact sexual liber consimţit, erau preocupate mai mult de activitatea sexuală, aveau un număr mai mare de parteneri sexuali, dar şi atunci când se angajau mai mult în comportamente sexuale riscante (de exemplu, relaţii sexuale neprotejate asociate cu riscul de avort). De asemenea, în rețeaua de relații sociale a fetelor care erau victime ale abuzului sexual, s-a observat un număr mai mic de persoane de acelaşi gen, ceea ce poate fi rezultatul unui comportament de retragere şi izolare socială. În acelaşi timp, tatăl natural (figura paternă) a tins să lipsească din rețelele victimelor abuzului sexual. Astfel, $77.45 \%$ dintre fetele din grupul de control (faţă de numai $63.6 \%$ dintre fetele abuzate sexual) au inclus tatăl în rețelele lor sociale. Victimele abuzului sexual comis de mai mulți agresori cu violență fizică au tins să raporteze comportamente opuse celor manifestate de către fetele din grupul de control: niveluri mai scăzute ale preocupărilor sexuale, o atitudine mai negativă faţă de relaţiile sexuale, o dorinţă mai scăzută de a se implica în relații sexuale, respectiv un nivel mai ridicat al responsabilității în utilizarea contraceptivelor. Fetele care fuseseră victime ale unui singur agresor (în contextul unui abuz sexual comis fără violență) au tins să raporteze atitudini şi comportamente similare cu cele manifestate de către fetele din grupul de control. În baza constatărilor pe care le-au realizat, Noll, Trickett şi Putnam (2000) au concluzionat următoarele: a) victimele care sunt abuzate sexual de către taţii naturali tind să manifeste un comportament hipersexualizat; b) victimele care sunt abuzate de mai mulți agresori şi cu violență fizică tind să manifeste un comportament hiposexualizat şi c) victimele care sunt abuzate sexual de către un singur 
agresor şi fără violenţă fizică sunt cele mai adaptabile la activitatea sexuală ulterioară.

Abuzul sexual comis de către un părinte asupra propriului copil este mai traumatizant decât cel comis de alți agresori, pentru că implică distorsionarea relaţiei copil-părinte, pierderea încrederii în părinte şi provoacă dezorganizarea familiei (Erdmans şi Black, 2008). Abuzul poate începe sub forma unei relaţii romantice dintre fiică şi tată, în care, aparent, ambii îşi dau consimțământul, însă consecințele devin nefaste atunci când victima începe să-şi formeze propria părere despre ceea ce ar trebui să presupună o relație sexuală sănătoasă. Alte tinere se implică în relații sexuale cu figura paternă plecând de la premisa că doar astfel vor fi acceptate de către tați. Traumele experimentate din cauza abuzului sexual în copilărie afectează în mod diferențiat dezvoltarea psihosocială şi psihosexuală a tinerelor, determinând, la vârsta adultă, relații afective dezechilibrate, probleme interpersonale, dificultăți în menținerea unor relații de prietenie sănătoase, conflicte cronice cu cei apropiați şi cu partenerii de viață. Tinerele abuzate sexual tind fie să se izoleze social, fie să se asocieze unor grupuri cu statut social scăzut, formate dintr-un număr mic de persoane de acelaşi gen. Izolarea de grupurile de prieteni cu un statut social sănătos se asociază unui număr de probleme emoţionale şi comportamentele pe care victimele abuzului sexual le experimentează în adolescență, precum consumul de alcool şi droguri, delincvență, depresie, stimă de sine scăzută etc. Cu referire la travaliul psihologic şi social al victimelor abuzului sexual, J. Musick (1993) nota: „Copila victimizată îşi formează anumite tipare de gândire în relaţia cu bărbații şi cu activitatea sexuală, care interacționează cu starea de vulnerabilitate emoțională şi o determină să repete victimizarea. În relația cu barbații, ea învață modele de pasivitate şi neajutorare. Abuzul sexual devine un liant în manifestarea sentimentului de neajutorare, dacă acesta nu este raportat sau dacă victimei nu i se recunoaşte abuzul, în urma raportării acestuia." (apud Erdmans şi Black, 2008, p. 78).

Unele victime ale abuzului sexual experimentat în copilărie percep într-un mod negativ statutul de femeie şi tind să considere îndeplinirea rolurilor de gen ca fiind de natură să le limiteze libertatea şi autonomia, manifestând comportamente masculinizate (Gaines, 1993; apud Erdmans şi Black 2008). Feminitatea este asociată vulnerabilității de a fi victimizată şi identificării $\mathrm{cu}$ agresorul. În mod alternativ, rolurile masculine oferă victimelor mijlocul prin care să-şi nege trauma şi să se apere împotriva sentimentului de vulnerabilitate şi neajutorare care se asociază abuzului. Adolescenții se simt mai încurajați să vorbească despre abuzul sexual atunci când au alături o persoană de încredere: un părinte, un consilier sau un 
profesor. Totuşi, într-un mediu familial agresiv şi neglijent, şansele unei adolescente de a stabili o relație de încredere cu un adult sunt extrem de mici. În această situație, condițiile care creează premisele unui abuz sunt aceleaşi cu cele care descurajează tânara să vorbească persoanelor care ar trebui să o protejeze şi care ar putea să o ajute. Conform constatărilor unor studii, mai mult de jumătate dintre victimele care s-au destăinuit altor persoane au fost acuzate de a fi responsabile pentru ceea ce s-a întamplat sau nu au fost crezute absolut deloc (Erdmans şi Black, 2008).

\section{Concluzii}

Conceptualizată ca un proces de tranzacție sau schimb între diferite entități, studierea rețelelor sociale presupune explicarea impactului pe care această structură $\hat{1}$ are asupra interacțiunilor umane şi asupra comportamentelor individuale. În contextul modelului de intervenție socială în rețea (Muntean, 2001), intervențiile trebuie să urmărească cu multă creativitate şi sistematic iniţierea şi funcționarea rețelelor sociale în care sunt ancorate familiile care se confruntă cu situații de maltratare a copiilor şi, în primul rând, al copiilor victimizați prin astfel de incidente. Experiența unor proiecte a demonstrat eficiența, costurile mici şi rezultatele remarcabile ale acestor tipuri de intervenție. În astfel de situații, rețelele de suport se alcătuiesc din serviciile şi profesioniştii implicaţi în intervenţie, dar şi din persoane exterioare sistemului de servicii sociale. Aceste persoane pot fi membri ai familiilor extinse sau pot fi voluntari care se implică pentru sprijinirea copiilor maltratați şi a familiilor acestora, precum şi a instituţiilor ofertante de servicii de asistență. Totodată, rețelele şi grupurile de suport social au un efect educativ şi terapeutic incontestabil, care, în anumite situații, poate fi mai adecvat decât o anumită formă de terapie şi, întotdeauna, poate completa cu succes o formă de terapie individuală.

Sistemele (rețelele) de suport social formal au o importanță deosebită pentru mamele care se confruntă cu diverse situații de viață stresante şi copiii acestora. Sistemele de suport ar trebui să ofere servicii de îngriijire a copiilor, sprijin material şi oportunități educaţionale de dezvoltare a mamelor, cu scopul de a reduce probabilitatea aplicării relelor tratamente copiilor. Sistemele de asistență socială ar trebui să asigure mamelor satisfacerea nevoilor de bază pentru copiii lor, ajutându-le, astfel, să facă faţă stărilor de furie sau de frustrare cauzate de stres şi, prin urmare, să fie mai puțin susceptibile de a comite abuzuri asupra propriilor copii sau de a-i neglija.

Deoarece izvorul abuzului şi al neglijării copilului atât în familie, precum şi în celelalte medii sociale care au responsabilitatea îngrijirii şi a 
acompanierii acestuia în procesul de dezvoltare psihosocială stă, în mare măsură, în reprezentările sociale cu privire la relația adult-copil, educația întregii comunități poate reduce incidența maltratării. Campaniile de sensibilizare la nivel comunitar şi politic pot influenţa contextul sociocultural al intervențiilor. Funcționarea rețelelor sociale este condiționată de nivelul de educație al membrilor comunității. Educația determină sensibilitatea şi disponibilitatea comunităţii de a ajuta. Voluntariatul, indiferent de tipul de proiect de intervenție în care este inclus, este facilitat de schimbarea reprezentării comune asupra fenomenului abuzului şi al neglijării, în sensul de a nu tolera producerea lui şi de a avea deschiderea necesară implicării reparatorii în situații de abuz sau neglijare a unui copil.

\section{Bibliografie:}

Baron-Cohen, S., Leslie, A. M., \& Frith, U. (1985). Does the autistic child have a theory of mind? Cognition, 21(1), 37-46.

Bishop, S. J., \& Leadbeater, B. J. (1999). Maternal social support patterns and child maltreatment: Comparison of maltreating and nonmaltreating mothers. American Journal of Orthopsychiatry, 69(2), 172181.

Buzducea, D. (2005). Aspecte contemporane în asistenţa socială. Iaşi: Editura Polirom.

Coohey, C. (2007). Social networks, informal child care, and inadequate supervision by mothers. Child Welfare, 86(6), 53 -66.

Coohey, C. (2001). The relationship between familism and child maltreatment in Latino and Anglo Families. Child Maltreatment, 6(2), 130-142.

Coohey, C. (2000). The role of friends, in-laws, and other kin in fatherperpetrated child physical abuse. Child Welfare, 79(4), 373-402.

Coohey, C. (1996). Child maltreatment: Testing the social isolation hypothesis. Child Abuse and Neglect, 20(3), 241-254.

Crittenden, P. (1988). Family and dyadic patterns of functioning in maltreating families. In K. Browne, C. Davies, \& P. Stratton (Eds.), Early Prediction and Prevention of Child Abuse (pp. 161-189). Londra: John Wiley \& Sons, Ltd.

Erdmans, M. P., \& Black, T. (2008). What they tell you to forget: From child sexual abuse to adolescent motherhood. Qualitative Health Research, 18(1), 77-89.

Gaudin, J. M. (2001). The role of social supports in child neglect. In T. D. Morton, \& B. Salovitz (Eds.), The CPS Response to Child Neglect: An 
Administrator's Guide to Theory, Policy, Program Design and Case Practice (pp. 108-111). Duluth, GA: National Resource Center on Child Maltreatment.

Iluţ, P. (1997). Abordarea calitativă a socioumanului: concepte şi metode. Iaşi: Polirom.

Muntean, A. (2001). Intervenția. În Ionescu, Ş. (Coord.), Copilul maltratat. Evaluare, prevenire, intervenţie (pp. 125-164). Bucureşti: Fundaţia Internațională pentru Copil şi Familie.

Noll, J. G., Trickett, P. K., \& Putnam, F. W. (2000). Social network constellation and sexuality of sexually abused and comparison girls in chilhood and adolescence. Child Maltreatment, 5(4), 323-337.

Orford, J. (1998). Psibologia comunității. Teorie şi practică (trad.). Bucureşti: Editura Oscar Print. 